\title{
Jackie the Greek: The Onassis \\ Marriage and the Hellenization \\ of an American Icon
}

\section{David Wills}

\author{
Neograeca Bohemica $20|2020| 9-23$
}

\begin{abstract}
A 1968 series of satirical audio sketches concerning the marriage and lifestyle of Aristotle Onassis and Jacqueline Kennedy provides an opportunity to re-examine the reputation of this famous couple. These recordings connect with well-known negative assumptions - both in the contemporaneous media and in the previously restricted governmental files from the British National Archives used here - about Kennedy's cynicism and Onassis' Greek heritage. It will also be argued here that Jackie's attempts to engage with Greece, especially Modern Greece, were a deliberate choice as part of her new identity, but in reality merely contributed to her damaged image.
\end{abstract}

\section{Keywords}

Onassis, Hellenism, American satire, Skorpios, Greek shipowners 
In the 1960 Jacqueline Bouvier made the journey from American idol to fallen Greek goddess. Already in her time as First Lady, she had introduced Ancient Greek culture to JFK, leading to the adoption of classical themes in Presidential rhetoric and antique gowns at White House balls. Her subsequent marriage to Aristotle Onassis enabled her to become part of Modern Greece too. But although Jackie delighted in exploring her adopted country's lifestyle, becoming a Modern Greek had its pitfalls as well as practical benefits. It caused widespread damage to her reputation amongst the American media and public. This was not merely because of her marriage to a wealthy, older man. It was also because being a Modern Greek did not have the same perceived cultural value as 'Ancient'. Jackie's choice of successive husbands, according to one Bronx wit, went "from a Greek God to a goddam Greek". ${ }^{1}$ From the Oriental habits which were allegedly the legacy of Turkish occupation, to the fragile grip on modern democratic standards demonstrated by the arrival of the Colonels in 1967, the Western imagination saw the Greeks as a debased people who had fallen from their Olympus. ${ }^{2}$ Greeks were also judged to be incapable of understanding style and fashion: a prime example, cited by Kelsey Swanson, was Onassis' use of whale foreskins in the decoration of his yacht. ${ }^{3}$

Given the fame of the Onassis couple, it is surprising that, as Oline Eaton has explained, "Scholarly enquiry into the influence of Jacqueline Kennedy Onassis [...] has been slow and the scholarship remains limited."4 Likewise, "there are almost no academic studies" of Aristotle Onassis himself. ${ }^{5}$ In contributing to this thus-far rare academic analysis, this article is not focused on the 'reality' of the lives of two people who were, variously at different times and in different contexts, the subjects of admiration, emulation, envy and ridicule. Instead, I consider public perceptions of them through a case-study: an American series of comedy sketches by Bob Booker and George Foster. Booker and Foster's writing was both popular and influential: their original success, The First Family (1962), about the Kennedys in the White House, sold over seven million copies on LP before winning Album of the Year at the Grammy Awards. ${ }^{6}$ For Bob Booker in particular, this was the springboard for a television career which lasted over forty years, in which he worked with Ed Sullivan, Burt Reynolds

1 Fraser et al. (1977: 255). My thanks to the staff of the National Archives, Kew, London, for access to British government files used in this article.

2 Wills (2007: 104-105).

3 Swanson (2005: 75-76).

4 Eaton (2019: 320).

5 Harlaftis (2014: 243).

6 Robinson (2010: 133-134). 
and Sammy Davis Jr. amongst others. ${ }^{7}$ Yet the LP from 1968, entitled Beware of Greeks Bearing Gifts, has previously been overlooked as an example of the representation of Jackie and Ari, and my aim is to remedy this by considering its relationship to popular discourse about the Onassis newlyweds.

Eaton has argued that Jackie "never had control" over her life-narrative. ${ }^{8}$ After outlining the key themes in Ari's popular image which led to a backlash against his marriage, I will go on to argue that Jackie attempted to reclaim the narrative of her life and its meaning through recasting herself as Greek, and specifically as a Modern Greek. For Jackie, becoming a Modern Greek meant freedom: from worries over money, from the paparazzi, and from the stifling expectations of the Kennedy legacy. Beware of Greeks Bearing Gifts is an example of how it was others - the media, newspapers, biographers, photographers who, inevitably, constructed and exploited the Jackie image and story. Going Greek could have different meanings, and the comic writers of 1968 subverted this into some common stereotypes which frustrated Jackie's efforts at forging a new (Greek) identity.

\section{Ari, the Tarnished Golden Greek}

From humble beginnings, Ari had, by the 1960s, become the global 'King of Tankers'. ${ }^{9}$ The most commented-upon aspects of his lavish lifestyle were his yacht, named after his daughter Christina, and his own Ionian island, Skorpios, which he bought in 1962. Stories of extravagance sold newspapers: "The Christina reportedly featured forty-two telephones, faucets made out of gold, and a huge swimming pool, not to mention two El Greco paintings, a $\$ 25,000$ jade Buddha, and barstools covered with the foreskins of whales." 10 The yacht's guest-list sparkled with film stars such as Marlene Dietrich, Douglas Fairbanks, Greta Garbo, Ava Gardner and Cary Grant, who were served with the finest of wines by the resident sommelier and dined on a choice of French or Greek cuisine. ${ }^{11}$ Even journalists who were broadly his critics, such as the celebrated newspaper-owner Helen Vlachos, had to concede that in conversation Ari was "pleasant, friendly, informative". ${ }^{12}$ The closest that Onassis ever came to an official biographer, Willi Frischauer, was almost homoerotic

7 Bob Booker Collection. Writers Guild Foundation Archive (accessed $2{ }^{\text {nd }}$ June 2020).

8 Eaton (2019: 318).

9 Harlaftis (2019: 172).

10 Swanson (2005: 75-76).

11 Fraser et al. (1977: 166).

12 Vlachos (1970: 109). 
in his choice of compliments about his subject's physical appearance whilst water-skiing as a young man in America: "His bronzed muscular body flitting across the sea at break-neck speed looked like the Greek god Hermes."13 Mariners from Ithaca, which Onassis came to regard as his adoptive home island, had good career prospects in his business: "70 percent of all 140 vessels that Onassis purchased in his lifetime were commanded at one point or another by Ithacan Masters." Those whom he so favoured reciprocated with praise, so that "testimonies of all who worked with him talk about a charismatic personality, hardworking, open to suggestions, creative, friendly, and a passionate businessman". ${ }^{14}$

But this 'Golden Greek' was accorded a largely hostile reception by the Anglophone press, by the American and British governments, and by self-styled arbiters of taste. Upon her marriage to Ari, Jackie brought in leading American designer Billy Baldwin to build new accommodation on Skorpios. Baldwin took the opportunity to also cast his eye over the Christina, the interior of which he judged to be "the ugliest thing I had ever set eyes on". ${ }^{15}$ Ari's personal appearance was damned by journalists as equally lacking in style: "By the age of twenty he had already acquired the knack of making a good suit look like a Salvation Army handout." ${ }^{16}$ In a graffito which popped up in the US, Ari was mocked for the height difference from his celebrity wife: "Jackie Onassis forgot to beware Greeks bearing lifts." ${ }^{17}$ Helen Vlachos found him to be obsessed with "ships, money, ships, family, ships...". ${ }^{18}$ She remarked cynically that the great class of shipowners of which he was such a prominent member was judged "by a different yardstick from the one used to measure normal people", especially in that "tax-dodging is a must". ${ }^{19}$

The American authorities were predictably unsympathetic towards such cavalier business attitudes. As early as 1942, Ari was put under surveillance by the FBI, but the issue which hit the newsstands and the law courts arose post-war, with investigations into his acquisition of American cargo ships which were by then, in peacetime, surplus stock..$^{20}$ In February 1954 an arrest warrant was issued, the main charge being "conspiracy to defraud the United

Harlaftis (2019: 259).

Baldwin (1974: 117).

16 Fraser et al. (1977: 34).

17 D’Angelo (1974: 4).

18 Vlachos (1970: 104).

19 Ibid., 103-104.

20 Harlaftis (2014: 252). 
States of America" ${ }^{21}$ This might be interpreted as naked protectionism, Ari's non-American origins being essential to the decision to pursue the case: "US shipowners and seamen were not happy at all with the Greek penetration of their business." ${ }^{22}$ A CIA report of July 1954, investigating the concerns of US oil companies about Ari's interests in the Middle East, caught the mood by electing to label him with a racial tag - "a smart Greek" ${ }^{23}$ Ari claimed he was badly maligned: "In England I would have been knighted, in America I was indicted!"24

Despite this comment about the country which might have honoured him, the British government - whose strategic business interests included world and especially, in a time of Cold War tensions, Western European oil and shipping also kept a rather sceptical and at times suspicious eye on Ari. Voluminous correspondence was generated from the late 1960 s to early 1970 over the protracted tendering process for a new oil refinery in Greece, the London government seeking to safeguard the profits of British oil companies working there. A 1969 message to London from the Ambassador in Athens, Sir Michael Stewart, was scathing about Ari's competition with his great rival, Stavros Niarchos: the latter had put a massive initial sum of money down, whereas Onassis "has so far produced nothing". ${ }^{25}$ In August 1971 the British Embassy in Athens relayed with apparent glee to the Foreign and Commonwealth Office that there was "a litigation currently going on in the Australian courts between Onassis and a syndicate of ingenious Greeks who have registered a bogus company in Australia under the title of Olympic Airways and are now trying to hold up Onassis for $\$ 3$ million to buy his own trade name back". The recipient added a tongue-in-cheek suggestion that someone "please put up a scheme" along the same lines in Britain. With Onassis at last pulling out of negotiations with the Greek government, A. E. Palmer of London's Southern European Department was relieved to see the back of the matter: "We shall at least now be free from the complexities - dangers, even - of dealing with Mr Onassis." ${ }^{26}$

British officials' comments on Ari's activities suggest that they shared with their American counterparts a negativity born from both his foreign status and their Cold War suspicions. Startlingly evoking a Middle Eastern stereotype, the British Embassy in Athens suggested that Onassis' deal with the Greek

21 Fraser et al. (1977: 100).

22 Harlaftis (2019: 208).

23 Fraser et al. (1977: 143).

24 Frischauer (1968: 208).

25 National Archives, Kew, London, T317/1477.

26 National Archives, Kew, London, FCO 9/1402. 
government had been wrecked because of his insistence on "bargaining like a carpet dealer". In London, R. L. Secondé of the Southern European Department noted that Ari was now negotiating behind the Iron Curtain for financial assistance in developing two new industrial plants in Greece, but: "Onassis' flirtation with the Russians (and probably the Hungarians) is mainly intended to get better terms from Western suppliers and from the Greek Government." Reporting to the embassy in Budapest, Secondé was especially colourful: "The manoeuvring over the Onassis contracts has been, will no doubt continue to be, so devious that it is never easy to describe with confidence the situation on any particular front. Like a jelly-fish, it is difficult to grasp and one is liable to be stung." 27

Although, as a refugee from the destruction of Smyrna, Ari's origins were outside of the modern nation state of Greece, he had from the start exploited his Greek heritage when making business contacts in Argentina and elsewhere. Later, at the height of his powers, Ari chose to develop his personal links with, and status in, his cultural homeland. If his semi-official biographer is to be believed, he seems to have considered himself a modern Odysseus: "They have much in common. They share the smell of the sea, the adventure-studded, peripatetic life, the unorthodox personality unfettered by the stereotype routine of lesser men and perhaps even the favour of the Gods." ${ }^{28}$ Ari's bid for the oil refinery was not the first time he felt called to do deals which were good for Greece as well as for himself. In the 1950 s he had reinvigorated the national carrier, Olympic Airlines, something he took on rather as a hobby or a favour: "He used to call it his mistress, while he called shipping his wife." ${ }^{29} \mathrm{He}$ faced criticism from some fellow Greeks over choosing to deal with the brutal military dictatorship which ran Greece from 1967-1974, participating in the no-tax and cut-price national assets of what Helen Vlachos termed the "Great Junta Sale". ${ }^{30}$ Returning to the Greek homeland and creating his island kingdom of Skorpios carried the risk of derision and scorn as a nouveau riche version of the genuinely aristocratic Odysseus. This (modern) Greek lacked the cool, classical style of the ancients: his boat, the Christina, was described by Baldwin as "the epitome of vulgarity and bad taste". ${ }^{31}$ Even his American wife worked to curb his ambition: according to Jackie, Ari had wanted his new house on Skorpios to be his "Acropolis", dominating the island from its highest point.

27 Ibid.

28 Frischauer (1968: 78).

29 Papadimitriou (2002: 101).

30 Vlachos (1970: 111).

31 Baldwin (1974: 117). 
Instead, however, she instructed her designer to deliver something more understated, in a more sensitive location - instead of a Parthenon, the equivalent of an Erechtheum. ${ }^{32}$

Thus, when Ari's marriage was announced, the reaction was a cocktail of envy, ridicule, suspicion, and Orientalism. The American response to him as a suitor for Jackie has been summed up by one of his biographers as "too old, too foreign, too small, too dark, and too rich". ${ }^{33}$ S. Y. Dawbarn, from the perspective of the British Embassy in Athens, claimed that Onassis was now visibly ageing. In meetings "he now had to make notes. Up to six months ago he never made a single note or committed a figure to paper." ${ }^{34}$ Although Ari was shorter than his fiancée, one American cuttingly observed that he did appear taller - "when he stands on his money". ${ }^{35}$

\section{Jackie, the American who turned (in)to a Greek}

President John F. Kennedy was beloved as "one of the most luminous of American folk heroes". Many rumours of his survival emerged amongst those who could not bring themselves to believe that he had been assassinated. One such story was that he had done a deal with his wife's Greek friend and had been "brought to Onassis's island in the Mediterranean to recuperate and to spend the rest of his days in peaceful isolation". This was the only explanation that some could fathom for the former First Lady's inexplicable behaviour: "How could Jackie, the naïve at heart have asked, be genuinely attracted to so old a man?"36

Jackie had been "an international icon of grace, style, and beauty" ${ }^{37}$ But, previously saluted as the noble widow, she now faced headlines such as "America has Lost a Saint", "Jackie, How Could You?" and "Jack Kennedy Dies Today a Second Time". ${ }^{38}$ Her decision to marry Ari was greeted with derision, as Kelsey Swanson has explained, not merely because of his age and wealth but also because he was "foreign, short, unattractive, and overweight" ${ }^{39}$ And, of course, in the previous decade Ari had been the subject of criminal charges in the US over

32 Ibid., 120-121.

33 Fraser et al. (1977: 255).

34 National Archives, Kew, London, FCO 9/1402.

35 Fraser et al. (1977: 255).

36 Rosenberg $(1976: 52,53,56)$.

37 Kashner - Schoenberger (2018: 6).

38 Ibid., 170.

39 Swanson (2005: 71). 
the sale of government oil tankers to a non-citizen. Jackie's friendship with Ari had garnered bad reviews - using frankly nationalistic terms - even whilst she was still First Lady, a White House staffer remarking scathingly upon her return from a cruise on the Christina that "Jackie has stars in her eyes - Greek stars". ${ }^{40}$

Jackie's motives for this new marriage have been subject, then as now, to misunderstanding and misogyny. One biographer at the time portrayed Ari as "the indulgent squire of a gold-digging hedonist". ${ }^{41}$ That money was of some importance is suggested by her decision to negotiate a pre-nuptial agreement which included Ari agreeing to "pay all of her expenses while their marriage lasted" ${ }^{42}$ Jackie spent \$1.25 million in the first year of her marriage alone, most of it allegedly on clothes from New York which were never worn.${ }^{43}$ But the money, the power, the private island, and the luxury yacht, which Ari brought to the marriage were no mere lifestyle choices for Jackie. They were also the insurance for her family: security for the children she had with America's slain president and privacy from the prying eyes of the press for herself, the world's most famous woman. This was, in short, "the kind of sanctuary Jackie needed" . ${ }^{44}$

Joining Ari in his island hideaway was far from Jackie's first encounter with Greece's culture and people. Nancy Sultan has argued persuasively for Jackie's credentials as a Hellenist in the White House. As First Lady, Jackie had shown "her own ambitious agenda for the JFK administration and developed an ingenious way to promote it - through classical allusions". JFK came under the influence of Jackie's learning and vision: he "was already a reader of ancient history, but after he married Jackie he began regularly to reference classical authors and Greco-Roman ideology in his speeches." This was, however, no vague or general classicism, Sultan argues, but was specifically and consciously ancient Greek, not Roman: it was "Periclean Athens that guided the Kennedys". During one oration, he claimed that "Pericles told ancient Athens that it should be the school of all Greece. America today can be the school of all the world". Jackie used visual clues to promote this vision: "For one of the most important public events hosted by the White House, Jackie chose a Cassini designed Greek peplos." This item for a 1962 dinner was described by Oleg Cassini as "Grecian-style greenish-gray mossy colored gown in soft jersey", and a "liquid columnar dress suggestive of ancient statuary". ${ }^{45}$

40 Fraser et al. (1977: 247).

41 As quoted by Fraser et al. (1977: 314).

42 Kashner - Schoenberger (2018: 164).

43 Fraser et al. (1977: 258, 307).

44 Kashner - Schoenberger (2018: 160).

45 Sultan [2011]. 
I wish to develop this argument of Jackie's Hellenism by suggesting that a significant measure of the anger at her choice of marriage, post-assassination, derived from her decision to become a Modern Greek. Part of the alleged betrayal of the Kennedy reputation was due to her decision, as a widowed Catholic, to marry a divorced Greek Orthodox man in a Greek Orthodox ceremony. ${ }^{46}$ She had first toured Greece with her sister, Lee, in 1961, and had immediately loved the country with its "blinding sunlight, calm seas, and ancient olive groves". ${ }^{47}$ In choosing to begin life anew in Greece, in the wake of the Kennedy tragedy, Jackie hoped for liberation and was in search of "paradise lost" ${ }^{48}$ In Greece, she was welcomed as a Greek. According to Billy Baldwin, she was greeted by "an enormous cheering throng" in Athens; in contrast to America, "the masses of people were in love with Jackie, not mourning with her". ${ }^{49}$ On Skorpios, "Jackie learned Greek and embraced Greek culture, learning to dance the traditional surtaki and, on one occasion, dressing in the native dress of Corfu. She learned how to make dolmades; she made arrangements from the orchids, tulips, and roses that grew on the island".$^{50}$ Late at night, Jackie would gift guests on the Christina with Turkish delight. ${ }^{51}$

For many Western observers, however, being a Modern Greek simply did not have the same cachet as being Ancient. For those educated in Britain or America in the first half of the twentieth century, the distant past of Greece was uncontested as the height of world culture. ${ }^{52}$ Positive attributes inherited from the past included the democratic instincts of the city-state of Athens. According to a 1950 s book targeted at American young people, "Greece is still very much a land of free-thinking and free-speaking people". ${ }^{53}$ Less positively, the Modern Greeks were seen as corrupt and venal, having fallen from Olympus. ${ }^{54}$ After centuries of Turkish occupation, this debased people were suspect due to their fragile grip on modern democratic government, as shown during the right-wing Metaxas dictatorship of the 1930s, the left-wing attempted revolution of the Civil War, and the military rule of the 1967-1974 Junta. In identifying with the nation of her husband, Jackie hoped for practical and intellectual freedom, but

46 Swanson (2005: 78).

47 Kashner - Schoenberger (2018: 3).

48 Ibid., 4.

49 Baldwin (1974: 115).

50 Kashner - Schoenberger (2018: 175).

51 Baldwin (1974: 118).

52 Wills (2007: 36ff).

53 Gianakoulis (1958: 15).

54 A further 1968 example is in Wills (2020). 
was taking a huge risk. She would be seen as having fallen from the Classical heroine of the White House years, to the more questionable state of being a Modern Greek.

\section{American satire: Beware of Greeks Bearing Gifts}

In 1962, The First Family, a recording starring Vaughn Meader as President Kennedy, had become an unlikely American hit, a "national sensation and the best-selling LP of any kind to that time". ${ }^{55}$ Its influence has been explored at length by Peter M. Robinson:

Americans played the LP repeatedly during late 1962 and most of 1963, and even organized social occasions around playing it so that the performance could be experienced again and again with various audiences. Many people committed one-liners or entire sections to memory and then took great delight in becoming comedians themselves by imitating the comic's imitation of the president. Four decades before the term 'viral video' entered the vernacular to describe the rapid spread of sensational clips of news, entertainment, or political events among willing hosts on the Internet, Kennedy's wit and Meader's record made the comic performance of the presidency contagious within mass culture. ${ }^{56}$

In the wake of Kennedy's death, however, writers-producers Bob Booker, Earle Doud and George Foster asked for all unsold copies to be withdrawn. ${ }^{57}$ Lured by the huge public interest in Jackie Kennedy, Booker and Foster returned to the recording studio on November $24^{\text {th }} 1968$, little over a month since her wedding to Onassis and five years almost to the day since the assassination. Featuring Susan Anspach and Joe Silver in the lead roles, Beware of Greeks Bearing Gifts was, due to the huge success and impact of The First Family, heavily promoted: an advert on the front page of Billboard proclaimed it as the "comedy album of the year" which offered "a high-styled satire of the world's most famous newlywed couple". ${ }^{58}$ The sleeves of their previous albums had habitually included a disclaimer attempting to deflect their subjects' ire, ${ }^{59}$ so here the producers offered what now seems like a rather tongue-in-cheek apology: "American humor traditionally deals with those people of our time who are head and shoulders

\footnotetext{
55 Robinson (2010: 130).

56 Ibid., 141.

57 Ibid., 137.

58 Billboard (21 December 1968: 1).

59 Robinson (2010: 137).
} 
above the rest of us ordinary mortals. It is to those 'larger than life' people that this album is respectfully dedicated." Yet in their twenty sketches over two sides of an LP, Booker and Foster presented a far from affectionate portrait of Ari and Jackie's style, habits, obsessions and racial background, perpetuating from the start some pernicious stereotypes about Greeks. Although its cultural reach is hard to gauge - its high point was 190 in the Billboard chart - I will argue that Beware of Greeks Bearing Gifts contributed to the negativity surrounding the efforts of the world's most revered widow to draw a line and move on. ${ }^{60}$

The record's sleeve illustration is dominated by a caricature of the newlyweds in which Ari is shown as considerably shorter than his bride, grey-haired and swarthy, with an outsize nose - a grotesque physical stereotype of a Greek. In fact, throughout the comedy sketches, Ari's Greekness is a focus for ridicule. Making his first appearance in side 1's second track (hereafter 1.2, etc.), Ari's conversation with his mother is conducted in pseudo-Greek accents, reinforcing the 'foreigner' rhetoric which I have shown was employed in American government circles and the media more widely. Conforming to listeners' expectations about the relationship between 'Mediterranean' sons and mothers, and in accordance with Helen Vlachos' personal finding of 'family' being one of Ari's obsessions, whilst Mrs Onassis dotes on her 'Golden Greek', he is particularly anxious to reassure her that he is marrying into "real aristocracy", although she assumes that this must mean a nice local girl. At the wedding itself (1.4), a clear division of nationality is assumed of the guests, with arrivals who possess outlandish names ("Mopopopoulos") being shown as a matter of course to the groom's side of the church. The writers take the opportunity to insert a reference to another internationally-known Greek by imagining that Ari's former companion Maria Callas is locked in a side room for fear that she will disrupt the vows. Later, when Jackie receives a court summons in New York over a parking ticket, Ari promises to fix it for her. His solution, picking up the phone to US Vice President-elect Spiro Agnew, plays on the widespread prejudice of corrupt Greeks looking after their own (2.1). The insinuation that Ari regarded himself as above the normal rule of law, whether over parking offenses or government taxes, is also referenced through his decision to fire a torpedo at a boatload of troublesome reporters (2.2). Favouritism towards employing Greeks is criticised through Ari's yacht crew being described on parade as "a swell bunch of foreigners" by the American Jackie, with the oft-cited extravagance of life aboard the Christina being emphasised by the sound effect of a marching army as they disperse (1.9).

60 https://www.billboard.com/charts/billboard-200/1969-02-01. 
The sketches relentlessly target Ari's affection for money, a quality which I noted was prominent in the pen-portrait by journalist Helen Vlachos, together with his alleged lack of style, taste and sophistication. The doorbell of his mansion chimes with the sound of a cash-register, and his preferred evening reading material is an accounts book - he professes to love a story with a happy ending $(2.5,1.9)$. Reflecting the obsession with ships noted by Helen Vlachos, Ari greets his mother with a gift which seems to him a "mere knickknack" - an oil tanker (1.2). In conversation with her sister Lee, Jackie similarly emphasises her new husband's excesses by complaining that when she needs a quarter for the ladies' room, he has bags of cash delivered (2.3). Although aspiring to the height of sophistication by ordering salmon from Scotland and beef from London, Ari shows his lack of class by insisting that the deposit on returned empty Coke bottles be taken off the grocery bill. Reporting a robbery at their 158-room mansion, the couple reveal that they have had jewels and a sketch by Michelangelo taken - all from the bathroom (2.5).

The writers regularly denigrate Ari's physical appearance and attributes, perhaps inevitably for comedic purposes overlooking the positive qualities of charisma and vigour noted by his associates and biographers. Members of the press are portrayed as focusing on his baggy suits, for example, and Jackie's frustrated efforts to measure him for a sweater prove to be the setup for a joke about his diminutive stature, the punchline being his protest that "I am standing up" $(1.7,1.9)$. During the same scene of married domesticity, Ari asks Jackie to fetch his glasses for him, but by the time she gets back, he's snoring, befitting his status as an older bridegroom which was so relentlessly referenced by commentators prior to the marriage.

In their representation of Jackie, Booker and Foster inevitably question the motives of her union with this older, unattractive, wealthy, Greek. The First Family had portrayed Jackie as a First Lady who showed appropriate concern when in conversation with JFK about their "out of control" official catering budget, whilst simultaneously summoning a designer from France to produce a dress exclusive to her. Beware of Greeks Bearing Gifts similarly seeks to expose her obsession with conspicuous expenditure. For example, in the aftermath of the Onassis wedding, Jackie initially reflects on how "gorgeous" and "elegant" it was, whereas Ari, seen as a vulgar and foreign (non-American) nouveau riche, wallows in how much it cost. But when interviewed about their future life together, her mask slips: Ari is looking forward to "extreme happiness", while Jackie cites how much money they will have (1.5). Her bank account rapidly enters the red and she spends one million over the subsequent year $(1.9,2.9)$. 
As a new bride, Jackie is consistently shown as shallow in her pursuit of celebrity. The very first sketch in Beware of Greeks Bearing Gifts presents her as determined to court publicity by spending hours posing for photographers under the hot sun of Skorpios, even though she complains "my girdle is killing me" (1.1). Her pretensions to being cultured are merely a veneer. In The First Family, JFK is heard complaining that her choice for a Saturday-night movie is an "abstract Swedish picture", but Jackie is completely unable to supply the television crew she is showing around the White House with any useful information about the historic paintings on show. In both LPs, she chooses to associate with individuals because of their cultural and intellectual credentials. Upon their arrival at the White House, dinner guests in The First Family are greeted by Jackie with striking familiarity, Leonard (Bernstein) being followed by Albert (Schweitzer). Bernstein makes a further appearance in Beware of Greeks Bearing Gifts (1.4), along with Truman Capote, Margot Fonteyn and Rudolf Nureyev as Jackie's guests, whereas Ari is mocked for choosing to socialise with the less glamorous Spiro Agnew (2.9, 2.10). As I explained earlier, Ari regularly entertained film stars aboard the Christina, but to emphasise that Ari's selection was based on political power and Greek-networking rather than sophistication, Booker and Foster reduce Agnew to a child who spends his time at home playing on a swing in his backyard and who is unable to tell the time (2.10). When the newly-married Jackie, desperate not to appear desperate for validation, is informed that she is receiving congratulatory messages and requests for meetings - from her sister, her dress-maker, the press - she laconically agrees to speak to them later. But reflecting the allegation I noted earlier of betraying her Catholicism through going Greek in her marriage, when the Vatican phones, Jackie responds "tell them I'm not in" (1.3).

Jackie is portrayed as being fully aware of the problematic image of the man she has taken on and attempts to improve this by coaching him in what to tell a reporter: he is 6 foot 1, aged 49, and has a net worth of 25 billion. In this she fails, because he is made to look foolish beyond redemption by correctly giving these rehearsed answers to the expected questions, but in the wrong order (2.5). When Prince Ranier arrives for dinner aboard the Christina, his wife Grace (née Kelly) remains bitter with Ari about the power struggle the two men had over control of Monaco (2.7). It is a new feud which really exercises Jackie, however: not only does Princess Grace belittle the husband of her fellow style icon for his shiny suit, but more significantly she also criticises Jackie's dress sense: "Is that the latest thing in Greece? No gown, just wrap yourself in grape leaves?" Jackie is so incensed with this slight to her new Greek status that, immediately afterwards, she pulls in the yacht's gangplank, pitching the departing royal 
couple into the sea (2.7). As has been explained by her biographers, Jackie's choice of Ari was designed to not merely give her continued financial benefits, but also status and security in a world where she had been left alone to face unprecedented media and public interest. But as I have suggested, Jackie was also refiguring her identity as Greek. In Booker and Foster's satirical sketches, Jackie had announced her new role by posing for the cameras in the sunshine of a Greek island. But Princess Grace's dismissal of Jackie's personal appearance posts a warning that this Greek persona would not universally receive a warm welcome.

\section{Conclusion}

In their satire of the Onassis-Kennedy marriage, Booker and Foster naturally tap into public criticism and perceptions of the 'happy couple'. Ari is swarthy, grey-haired, of short stature and a big nose, and his age is emphasised by him dozing off in his chair. He is concerned only with money, is uncultured, and has no sense of style. He believes he can use to his advantage his connections in the Greek community, with the resulting corruption of the legal system. Both in appearance and character, I have shown that much of this relates to American and British stereotypes of Greeks, and to dubiousness of Onassis both as a (foreign) man and a business leader. In marrying Ari, Jackie's reputation has, in Booker and Foster's view, declined from her former status as 'First Widow', and she is seen overwhelmingly as shallow. Her dinner and wedding guests are chosen from the ranks of American literati and celebrity, she has disdain for people who slight her, and her own obsession with wealth is represented as explaining fully her new choice of husband.

In reality, Jackie's motives were more complex. In the White House, Ancient Athens had been her inspiration, a choice which received appropriate acclamation as statesmanlike. Once cast outside the Washington bubble, Jackie's appearance was observed by critics as having changed from goddess to "grape leaves". Her 'descent' to associate with Modern Greeks, a people who inherited a glorious heritage but were now unfairly regarded as possessing merely a sad reflection of their past glories, seemed to fit with the rest of her tarnished reputation. She was, for better or worse, making a conscious decision that her new path would take her to Greece. Previously America's darling, in 1968 Jackie did not just marry a Greek, she became a Greek. 


\section{Bibliography}

\section{Primary sources}

Billboard (magazine). 21 December 1968.

Bob Booker Collection. Writers Guild Foundation Archive [https://oac.cdlib.org/findaid/ ark:/13030/c86w9gjq/].

National Archives, Kew, London. FCO 9/1402: UK General Policy toward Aristotle Onassis' (Shipping Tycoon) Investments in Greece [http://discovery.nationalarchives.gov.uk/ details/r/C11011634].

National Archives, Kew, London. T317/1477: Contract for Building and Supplying a Third Oil Refinery in Greece [http://discovery.nationalarchives.gov.uk/details/r/C10919978].

Commercial audio recordings

Booker, B. - Doud, E. - Foster, G. 1962. The First Family. Cadence Records: New York.

Booker, B. - Foster, G. 1968. Beware of Greeks Bearing Gifts. EMI: London - New York.

\section{Secondary sources}

Baldwin, B. 1974. Billy Baldwin Remembers. New York - London.

D’Angelo, F. J. 1974. Sacred Cows Make Great Hamburgers: The Rhetoric of Graffiti. College Composition and Communication 25, 173-180.

Eaton, O. 2019. Jacqueline Kennedy Onassis: A Celebrity Afterlife in American Culture. Journal of American Studies 53/2, 317-332.

Fraser, N. - Jacobson, P. - Ottaway, M. - Chester, L. 1977. Aristotle Onassis. London.

Frischauer, W. 1968. Onassis. London.

Gianakoulis, T. 1958. Greece and Her People. London.

Harlaftis, G. 2014. The Onassis Global Shipping Business, 1920s-1950s. Business History Review 88/2, 241-271.

Harlaftis, G. 2019. Creating Global Shipping: Aristotle Onassis, the Vagliano Brothers, and the Business of Shipping, c.1820-1970. Cambridge.

Kashner, S. - Schoenberger, N. 2018. The Fabulous Bouvier Sisters. The Tragic and Glamorous Lives of Jackie and Lee. New York.

Papadimitriou, S. 2002. The Other Aristotle Onassis: A Visionary Builder of Foundations. Mediterranean Quarterly 13/2, 96-107.

Robinson, P. M. 2010. The Dance of the Comedians: The People, the President, and the Performance of Political Standup Comedy in America. Amherst.

Rosenberg, B. A. 1976. Kennedy in Camelot: The Arthurian Legend in America. Western Folklore 35, 52-59.

Sultan, N. [2011] Jacqueline Kennedy and the Classical Ideal. Available from: https://chs. harvard.edu/CHS/article/display/4767 [10 June 2020].

Swanson, K. 2005. From Saint to Sinner and Back Again: Jacqueline Kennedy Onassis Rehabilitates Her Image. Historical Perspectives: Santa Clara University Undergraduate Journal of History 10, 70-86. Available from: http://scholarcommons.scu.edu/historical-perspectives/volio/iss1/9 [10 June 2020].

Vlachos, H. 1970. House Arrest. London.

Wills, D. 2007. The Mirror of Antiquity: $20^{\text {th }}$ Century British Travellers in Greece. Newcastle. Wills, D. 2020. Durrells and Donkeys: The Representation of Animals, Greeks, and Corfu in Gerald Durrell's The Donkey Rustlers. Byzantine and Modern Greek Studies 44/1, 154-169. 
